in the presence of distant metastases survival is usually less than two years. ${ }^{56}$ This is one of the youngest cases of adenoid cystic carcinoma reported in the literature.

The pneumonectomy specimen showed no histopathological features of MacLeod's syndrome. The radiological features discovered at the age of 15 years are therefore almost certainly a result of central airway narrowing due to the adenoid cystic carcinoma which was ultimately found eight years later.

Lack of radiological change over several years cannot therefore exclude the possibility of a malignant endobronchial lesion causing a unilateral hyperlucent lung.

1 Swyer P, James G. A case of unilateral pulmonary emphysema. Thorax 1953;8:133-6.

2 MacLeod WM. Abnormal transradiancy of one lung. Thorax 1954;9:147-53.

3 Fraser RG, Paré JAP. Diagnosis of diseases of the chest. 2nd edn. Philadelphia: W B Saunders, 1977:553-61

4 Turnbull AD, Huvos AG, Goodner JT, Beattie EF Jr. The malignant potential of bronchial adenoma. Ann Thorac Surg 1972;14:453-62.

5 Moran CA, Suster S, Koss MN. Primary adenoid cystic carcinoma of the lung. A clinicopathologic and immunohistochemical study of 16 cases. Cancer 1994;73:1390-7.

6 Conlan AA, Payne WS, Woolner LB, Sanderson DR. Adenoid cystic carcinoma (cylindroma) and mucoepidermoid carcystic carcinoma (cylindroma) and mucoepidermoid carCardiovasc Surg 1978;76:369-77.

\footnotetext{
Department of Chest

Medicine, Mont-

Godinne Hospital,

Catholic University

of Louvain,

5530 Yvoir, Belgium

O Vandenplas

J-P Delwiche

Y Sibille

Correspondence to:

Dr O Vandenplas.

Received 18 November 1994

Accepted for publication

16 January 1995
}

\section{Occupational asthma due to latex in a hospital administrative employee}

Olivier Vandenplas, Jean-Pierre Delwiche, Yves Sibille

\author{
Abstract \\ A case is described of occupational asthma \\ caused by indirect exposure to airborne \\ latex allergens in an administrative hos- \\ pital employee who never used latex \\ gloves. \\ (Thorax 1996;51:452-453)
}

Keywords: asthma, occupational diseases, latex.

There is convincing evidence that allergenic proteins from latex bind to cornstarch glove powder, ${ }^{1}$ become airborne, ${ }^{2}$ and have the potential to cause rhinitis and asthma. ${ }^{34}$ All cases of occupational asthma due to latex described so far have been in workers manufacturing ${ }^{5}$ or using ${ }^{346}$ latex gloves. We report a case of occupational asthma caused by latex in a medical secretary who had no direct contact with latex materials. This observation indicates that latex-induced asthma may result from purely indirect exposure to airborne latex in medical environments.

\section{Case report}

The subject was a 32 year old non-smoking women who experienced work-related rhinoconjunctivitis six months after starting employment as a medical secretary of a hospital emergency room in January 1988. About one year later she noticed chest tightness, wheezing, and coughing both at work and also at home after a work shift, during exercise, and when exposed to non-specific irritants. The symptoms never occurred at night and were easily relieved by an inhaled bronchodilator. Skin prick tests with common inhalant allergens gave negative results. In July 1993 asthma symptoms became noticeably less frequent. It was later noticed that around that time non-sterile latex examination gloves were replaced by vinyl gloves in the hospital. In December 1993 the subject developed contact urticaria when wearing household latex gloves. She denied having ever used cleaning gloves, medical gloves, or other latex materials including condoms before experiencing this urticarial rash. Although her office was completely separated from the emergency rooms, she occasionally had to walk through these rooms to carry medical files. However, she never stayed in the rooms for prolonged periods nor had direct contact with medical materials including gloves. She reported having had a caesarean section in 1982 and 1987 without allergic symptoms.

Skin tests using a commercial extract of latex (Stallergènes SA, Brussels, Belgium) elicited a $7 \mathrm{~mm}$ weal reaction. Total IgE concentration was normal $(59 \mathrm{IU} / \mathrm{ml})$ while a high level of specific IgE against latex $(10 \cdot 3 \mathrm{IU} / \mathrm{ml}$, Pharmacia CAP system, Uppsala, Sweden) was detected. Spirometric tests showed a forced expiratory volume in one second $\left(\mathrm{FEV}_{1}\right)$ of 3.251 (93\% predicted value) and a $92 \%$ predicted ratio of $\mathrm{FEV}_{1}$ to forced vital capacity (FVC). The subject showed marked nonspecific bronchial hyperresponsiveness as the provocative concentration of histamine causing a $20 \%$ fall in $\mathrm{FEV}_{1}\left(\mathrm{PC}_{20}\right)$ was $0.08 \mathrm{mg} / \mathrm{ml}^{7}$ Monitoring of peak expiratory flow rates (PEFR) at work was not carried out as the clinical history suggested that exposure to latex in the work place was only minimal at the time of evaluation. It was therefore decided to perform inhalation challenge tests with latex gloves in the laboratory. ${ }^{346}$ On the first day the subject handled vinyl gloves for 60 minutes in a $5 \mathrm{~m}^{3}$ challenge room without eliciting significant changes in $\mathrm{FEV}_{1}$ or in PEFR (figure). On the next day she was exposed to latex gloves (Triflex Surgical Gloves, Baxter Healthcare Corporation, Valencia, CA) for progressively longer periods of time. She was asked to shake each pair of gloves for three minutes while 


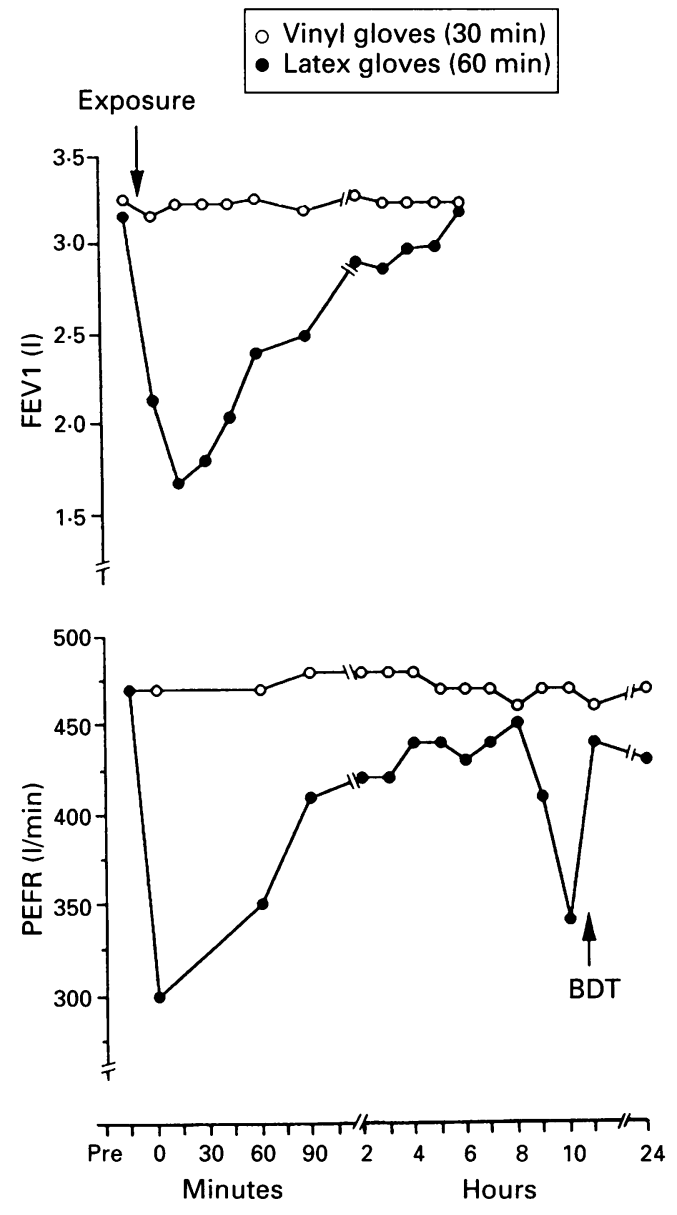

Changes in forced expiratory volume in one second (FEV) and peak expiratory flow rates (PEFR) after exposure to vinyl gloves (O) and latex gloves (O). $B D T=$ inhaled bronchodilator (salbutamol, $200 \mu \mathrm{g}$ ).

wearing vinyl gloves in order to prevent any direct contact of the latex with the skin. The subject experienced rhinoconjunctivitis after 10 minutes of exposure. A cumulative exposure for 60 minutes resulted in a $47 \%$ fall in $\mathrm{FEV}_{1}$ with spontaneous recovery over the next hours. Ten hours after the end of exposure the subject demonstrated a 25\% drop in PEFR values which reversed to normal after administration of inhaled bronchodilator.

\section{Discussion}

Occupational asthma due to latex has been reported to occur in $6 \%$ of glove manufacturing workers ${ }^{5}$ and in $2.5 \%$ of hospital employees using latex gloves. ${ }^{6}$ In our subject inhalation challenge with gloves elicited a dual asthmatic reaction, thus enabling identification of airborne latex as the causative agent of her asthma. To our knowledge this is the first account of latex-induced asthma in an administrative hospital employee who did not use latex gloves.
Although we did not quantify the amount of airborne latex allergens at the work place, it is likely that her occupational exposure to latex was only intermittent and of low intensity, resulting from the fact that she walked through the medical rooms several times a day without long term exposure. The diagnosis remained unrecognised for a long time because her occupational exposure to latex was purely indirect and therefore unsuspected. Sensitisation to latex was only considered at the time she experienced an urticarial rash when wearing cleaning gloves for domestic purposes. The work relatedness of her asthma symptoms might also have been confused by late bronchial reactions occurring after the work shift and by asthmatic symptoms due to non-specific stimuli.

IgE-mediated sensitisation to latex allergens has been described predominantly in subjects with direct cutaneous, mucosal, or visceral exposure to latex containing materials, including workers manufacturing latex products, health care providers, and patients undergoing multiple surgical procedures. ${ }^{8}$ Subjects with atopy are at increased risk of developing latex allergy. ${ }^{8}$ Several lines of evidence indicate that sensitisation to latex in our non-atopic subject was specifically related to inhalation exposure. The subject denied any non-occupational exposure to latex materials including household gloves and condoms. It is unlikely that caesarean sections contributed to the development of latex sensitisation since rhinoconjunctivitis symptoms occurred only several months after she started to work in the hospital.

This observation further indicates that latex proteins are potent aeroallergens causing a respiratory health hazard in subjects with limited and indirect inhalation exposure. The possibility of occupational asthma due to latex should be suspected and properly assessed even in workers who do not handle latex gloves but are indirectly exposed to airborne latex allergens in medical or industrial environments.

1 Turjanmaa K, Reunala T, Alenius H, Brummer-Korvenkontio $\mathrm{H}$, Palosuo $\mathrm{T}$. Allergens in latex surgical gloves and glove powder. Lancet 1990;336:1588.

2 Swanson MC, Bubak ME, Hunt LW, Yunginger JW, Warner MA, Reed CE. Quantification of occupational latex aeroallergens in a medical center. $\mathcal{F}$ Allergy Clin Immunol 1994; allergens in

3 Lagier F, Badier M, Charpin D, Martigny J, Vervloet D. Latex as aeroallergen. Lancet 1990;ii:516-7.

4 Jaeger D, Czuppon AB, Baur X. Latex-specific proteins causing immediate-type cutaneous, nasal, bronchial, and systematic reactions. $\mathcal{F}$ Allergy Clin Immunol 1992;89:75967.

5 Tarlo SM, Wong L, Roos J, Booth N. Occupational asthma caused by latex in a surgical glove manufacturing plant. $\mathcal{F}$ Allergy Clin Immunol 1990;85:626-31.

6 Vandenplas O, Delwiche JP, Evrard G, Aimont P, van der Brempt X, Jamart J, et al. Prevalence of occupational asthma due to latex among hospital personnel. Am $\mathcal{F}$ Respir Crit Care Med 1995;151:54-60.

7 Cockcroft DW, Killian DN, Mellon JJA, Hargreave FE. Bronchial reactivity to inhaled histamine: a method and clinical survey. Clin Allergy 1977;7:235-43.

8 Slater JE. Latex allergy. F Allergy Clin Immunol 1994;94: 